\title{
"The effect of the government bond value on the intermediary function of banks in the capital market of Indonesia"
}

\begin{tabular}{|c|c|}
\hline \multirow{3}{*}{ AUTHORS } & Rosemarie Sutjiati Njotoprajitno iD https://orcid.org/0000-0003-1627-1801 \\
\hline & Bram Hadianto (D https://orcid.org/0000-0001-9140-3216 \\
\hline & Melvin \\
\hline ARTICLE INFO & $\begin{array}{l}\text { Rosemarie Sutjiati Njotoprajitno, Bram Hadianto and Melvin (2020). The effect of } \\
\text { the government bond value on the intermediary function of banks in the capital } \\
\text { market of Indonesia. Banks and Bank Systems, 15(3), 199-206. } \\
\text { doi:10.21511/bbs.15(3).2020.17 }\end{array}$ \\
\hline DOI & http://dx.doi.org/10.21511/bbs.15(3).2020.17 \\
\hline RELEASED ON & Wednesday, 07 October 2020 \\
\hline RECEIVED ON & Thursday, 14 May 2020 \\
\hline \multirow[t]{2}{*}{ ACCEPTED ON } & Tuesday, 01 September 2020 \\
\hline & $((c)) E Y$ \\
\hline LICENSE & $\begin{array}{l}\text { This work is licensed under a Creative Commons Attribution } 4.0 \text { International } \\
\text { License }\end{array}$ \\
\hline JOURNAL & "Banks and Bank Systems" \\
\hline ISSN PRINT & $1816-7403$ \\
\hline ISSN ONLINE & $1991-7074$ \\
\hline PUBLISHER & LLC "Consulting Publishing Company "Business Perspectives" \\
\hline FOUNDER & LLC "Consulting Publishing Company "Business Perspectives" \\
\hline
\end{tabular}

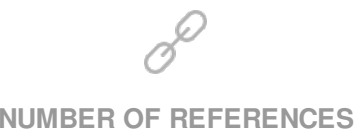

35



0
NUMBER OF TABLES

5

(C) The author(s) 2021. This publication is an open access article. 


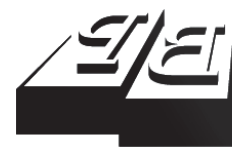

\section{BUSINESS PERSPECTIVES}

(O)

LLC "CPC "Business Perspectives" Hryhorii Skovoroda lane, 10, Sumy, 40022, Ukraine www.businessperspectives.org

Received on: $14^{\text {th }}$ of May, 2020 Accepted on: $1^{\text {st }}$ of September, 2020 Published on: $7^{\text {th }}$ of October, 2020

(C) Rosemarie Sutjiati Njotoprajitno, Bram Hadianto, Melvin, 2020

Rosemarie Sutjiati Njotoprajitno, Doctor, Lecturer, Management Department, Economics Faculty, Maranatha Christian University, Bandung, Indonesia.

Bram Hadianto, Doctor, Lecturer, Management Department, Economics Faculty, Maranatha Christian University, Bandung, Indonesia. (Corresponding author)

Melvin, Undergraduate Student Management Department, Economics Faculty, Maranatha Christian University, Bandung, Indonesia.

Rosemarie Sutjiati Njotoprajitno (Indonesia), Bram Hadianto (Indonesia),

Melvin (Indonesia)

\title{
THE EFFECT
}

OF THE GOVERNMENT BOND VALUE ON THE INTERMEDIARY FUNCTION OF BANKS IN THE CAPITAL MARKET OF INDONESIA

\begin{abstract}
The distribution of funds becomes the identity and function of banks. By performing this function well, the banks can get profit to survive. One of the considered factors affecting this channeling function is the issuance of government bonds to finance the state budget, which may be harmful to this bank channeling function. Therefore, to prove this situation, it is necessary to check a causal relationship between the government bond value and the bank intermediary function through this study, adding bank size and loans as a control variable.

This study utilizes the banks listed on the capital market of Indonesia as the population. Furthermore, the Slovin formula and a simple random sampling method are employed to determine the number of banks to be the samples and take them. Also, the regression model with pooled data and the t-statistic test are used to estimate its coefficients and examine the proposed hypotheses, respectively.

Overall, this study demonstrates that the government bond value positively affects the bank intermediary function. This indicates that the crowding-out does not exist. By this evidence, the government does not need to worry because this debt does not disturb the bank function to deliver the credit to society. Likewise, bank size and bad loans have a positive impact on this function. Thus, banks must be able to diversify risks among their assets and restructure bad loans when performing this function.
\end{abstract}

\section{Keywords}

JEL Classification

\section{INTRODUCTION}

The government of Indonesia has already issued and managed bonds to finance its budget following the Minister of Finance Decree No. 101/ KMK.017/2000. This circumstance has opened the opportunity for its citizens to join the national development and get the coupon regularly paid for the issued bonds that they have bought (Law No. 24 of 2002). Two arguments exist regarding the issuance of government bonds and the effect. First, the supporting one, as Abbas and Christensen (2007) demonstrate. They argue that by selling the bonds, the government can create macroeconomic stability, for example, reducing inflation and protecting the state from monetary crisis and other external crises. Second, the contra one, as shown by Hanson (2007). He declares that although domestic debt can help the capital market, the large amount of this debt has a similar risk to foreign debt.

Additionally, the issuance of government bonds can be a competition for banks to search for funds to redistribute them back to society in a 
loan. Consequently, what the government executes disturbs the intermediary function of commercial banks. This condition was supported by Christensen (2005) declaring the government debt goes down the bank lending to private sectors; DeBonis and Stacchini (2013) pointing out that the debt issued by the government drops the bank credit growth. Based on their study, Altayligil and Akkay (2013) suggest that the government should reduce its debt to facilitate the banks to distribute credits to the private sectors to enhance economic growth. Correspondingly, Anyanwu, Gan, and $\mathrm{Hu}$ (2017) confirm that government debt diminishes bank credit to private sectors. Similarly, Mwakalila (2020) shows that domestic government liabilities tend to cut bank credit.

Unfortunately, this crowding-out hypothesis has been broken by Utari, Kurniati, and Surjaningsih (2011), stating that government debt has a positive impact on a bank's ability to distribute funds; Akpansung (2018), announcing no effect; and Benayed and Gapsi (2020), finding that the inverted-U shape curve exists. Furthermore, they explain that under the starting point of 52\% of GDP, domestic public debt supports private banks for lending money. Upper this point, bank credits to the private sector fall.

This study also utilizes bank size and bad loans as the control variables. These variables are used because they become the determinants of the bank in channeling funds.

For bank size as the determinant of the bank intermediary function, the study of Shah, Khan, Shah, and Tahir (2018) and Khanal (2019) shows a negative effect. On the other hand, Vodová (2011), Chagwiza (2014), El-Chaarani (2019) display a positive impact. This positive effect of size on lending behavior is affirmed by Rabab'ah (2015), Boako, Acheampong, and Ibrahim (2017), Adzis, Sheng, and Bakar (2018), and Tran (2019). Meanwhile, Świtała, Kowalska, and Malajkat (2020) confirm a positive influence of the bank size on credit growth.

For bad loans as the determinant of the bank intermediary function, Ramadhani and Indriani (2016) and Somantri and Sukmana (2019) show a negative impact. Consistently, Rabab'ah (2015) confirms that the non-performing loan negatively influences bank lending behavior. Conversely, Akbar, and Mentayani (2010) and El-Chaarani (2019) illustrate a positive impact. When the bank credit distribution is measured by loan growth, Cucinelli (2015) and Ivanović (2016) reveal a negative effect.

This research intends to ensure the crowding-out phenomenon by investigating and analyzing the government bond effect on the bank intermediary function in the Indonesia capital market by employing its size and loans as a control variable.

\section{THEORETICAL FRAMEWORK AND HYPOTHESES DEVELOPMENT}

By issuing bonds to finance the state budget deficit, the government attracts the attention of the public to allocating money in this instrument. This condition makes money flow from the corporate bond market (Wibowo, Passagi, and Prasetyo, 2018) and the banking industry (Wibowo, 2018) to the government bond market (Wibowo, 2018; Wibowo, Passagi, and Prasetyo, 2018). Therefore, it disturbs the bank function to distribute credit to the private sectors, as confirmed by Christensen (2005), DeBonis and Stacchini (2013), Altayligil and Akkay (2013), Anyanwu Gan, and $\mathrm{Hu}$ (2017), Mwakalila (2020).Denoting this information, hypothesis la can be represented as follows:

\section{$H_{1} a$ : Government bond value negatively affects the intermediary bank function.}

The issuance of government bonds attracts the attention of commercial banks to investing money in government bonds. By having them in their asset portfolio, banks confidently distribute funds to 
private sectors because these bonds can compensate for the credit distribution risk (Utari, Kurniati, and Surjaningsih, 2011). Moreover, Utari, Kurniati, and Surjaningsih (2011) find that this bond value positively contributes to the rise in total credits for private sectors to the gross domestic product ratio. Denoting this information, hypothesis $1 \mathrm{~b}$ can be represented as follows:

\section{$H_{1} b$ : Government bond value positively affects the intermediary bank function.}

Banks' size reflects their capability to survive (Siringoringo, 2017), expand their business, and manage their asset portfolio (Kembuan, Rahman, and Setiawan, 2018). Unlike small banks, big banks can execute them; therefore, they can distribute loans based on the borrower asset guarantees, such as inventory, non-tangible assets, and accounts receivable (Uchida, Udellb, and Watanabe, 2008). These explanations are also affirmed by Vodová (2011), Chagwiza (2014), and El-Chaarani (2019). In the same way, the research of Rabab'ah (2015), Boako, Acheampong, and Ibrahim (2017), Adzis, Sheng, and Bakar (2018), Tran (2019), Świtała, Kowalska, and Malajkat (2020) supports this situation by inferring a positive effect of bank size on lending behavior. Given this argument and the previous research evidence, hypothesis two can be represented as follows:

\section{$\mathrm{H}_{2}$ : Bank size positively affects the intermediary bank function.}

Banks with high non-performing loans (NPL) have a liquidity problem so that they cannot distribute funds (Surjaningsih, Yumanita, and Deriantino, 2014), which is reflected in a higher LDR (Kartini and Nuranisa, 2014; El-Chaarani, 2019). In their research, Akbar and Mentayani (2010) and El-Chaarani (2019) confirm this situa-

Table 1. Research variables and their measurement tion by presenting a positive effect of NPL on LDR. Given this argument and the previous research evidence, hypothesis three can be represented as follows:

$H_{3}: \quad$ Bad loans positively affect the intermediary bank function.

\section{RESEARCH METHOD}

\subsection{Research variables and their measurement}

The variables in this study have two positions: outcome and explanatory. A bank intermediary function acts as an outcome. On the other hand, government bond value, bank size, and bad loans are explanatory variables. Table 1 shows the measurement of these variables.

\subsection{Population and samples}

The population of this study consists of the banks listed on the capital market of Indonesia during the period 2010-2018. By referring to the consistency-based observation, their number is 30 . Moreover, the number of samples $(n)$ that can represent the number of populations $(N)$ is counted by the Slovin formula in Suliyanto (2009) by using the error boundary (e) of $10 \%$. Moreover, this formula exists in equation (1).

$$
n=\frac{N}{1+N e^{2}}
$$

By denoting this formula, the number of samples

$$
n=\frac{30}{1+30(0.10)(0.10)}=\frac{30}{1.3}=23.07 \approx 23 .
$$

\begin{tabular}{|c|c|c|c|}
\hline Variable position & Research variable & Indicator & Scale of variable \\
\hline The outcome variable & Bank intermediary function & $\begin{array}{l}\text { Loan to deposits ratio (LDR) of the bank at the } \\
\text { end of the year }\end{array}$ & Ratio \\
\hline \multirow{3}{*}{ The explanatory variable } & Government bond value (GBV) & $\begin{array}{l}\text { Natural logarithm of monthly GBV (LNGBV) } \\
\text { accumulated for the year }\end{array}$ & Ratio \\
\hline & Bank size & $\begin{array}{l}\text { Natural logarithm of total assets of the bank at } \\
\text { the end of the year (LNTA) }\end{array}$ & Ratio \\
\hline & Bad loans & $\begin{array}{l}\text { Gross non-performing loans of the bank at the } \\
\text { end of the year (G_NPL) }\end{array}$ & Ratio \\
\hline
\end{tabular}


Likewise, we employ the simple random sampling method to take 23 banks as the samples. Assuring the randomness, we also utilize the random number generated by Microsoft Excel, as Hartono (2012) explains. After that, the names of the banks obtained are available in Table 2.

Table 2. Bank names serving as a sample

\begin{tabular}{|c|c|c|}
\hline No. & Code & Bank names \\
\hline 1 & AGRO & Bank BRI Agroniaga \\
\hline 2 & $\mathrm{BABP}$ & Bank MNC Internasional \\
\hline 3 & $\mathrm{BACA}$ & Bank Capital Indonesia \\
\hline 4 & $\mathrm{BBCA}$ & Bank Central Asia \\
\hline 5 & BBKP & Bank Bukopin \\
\hline 6 & $\mathrm{BBNI}$ & Bank Negara Indonesia 46 (Persero) \\
\hline 7 & BBNP & Bank Nusantara Parahyangan \\
\hline 8 & $\mathrm{BBRI}$ & Bank Rakyat Indonesia (Persero) \\
\hline 9 & BBTN & Bank Tabungan Negara (Persero) \\
\hline 10 & $\mathrm{BClC}$ & Bank JTrust Indonesia \\
\hline 11 & BDMN & Bank Danamon Indonesia \\
\hline 12 & $B J B R$ & BPD Jawa Barat and Banten \\
\hline 13 & BKSW & Bank QNB Indonesia \\
\hline 14 & $\mathrm{BMRI}$ & Bank Mandiri (Persero) \\
\hline 15 & BNBA & Bumi Artha \\
\hline 16 & $\mathrm{BNGA}$ & Bank CIMB Niaga \\
\hline 17 & BNII & Bank Maybank Indonesia \\
\hline 18 & $B V I C$ & Bank Victoria Internasional \\
\hline 19 & INPC & Bank Artha Graha \\
\hline 20 & MAYA & Bank Mayapada \\
\hline 21 & $\mathrm{MCOR}$ & Bank Windu Kencana Internasional \\
\hline 22 & MEGA & Bank Mega \\
\hline 23 & PNBN & Bank Pan Indonesia \\
\hline
\end{tabular}

\subsection{Data analysis method}

Referring to the variable scale in Table 1, this study uses the regression with pooled data adopting the ordinary least square method as the parameter estimation method (Nachrowi \& Usman, 2006). (Nachrowi and Usman, 2006). Additionally, this model can be seen in equation (2).

$$
\begin{aligned}
& L D R_{i t}=\beta_{0}+\beta_{1} \cdot L N G B V_{i t}+ \\
& +\beta_{2} \cdot L N T A_{i t}+\beta_{3} \cdot G_{-} N P L_{i t}+\varepsilon_{i t} .
\end{aligned}
$$

The regression model must reach the test of some classical assumptions to yield the best, linear and unbiased estimators (BLUE). In other words, this model's errors have to follow the normal distribution and be free from the impact of explanatory variables (the absence of heteroscedasticity). Additionally, there is no significant correlation between the independent variables (the nonappearance of multicollinearity).
The residuals have to be random (the absence of autocorrelation) (Ghozali, 2016).

- To attest to the normality of residuals, the Kolmogorov-Smirnov test was used. The normality happens when the asymptotic significance of the Z-statistic of K-S is higher than a significance level $(\alpha)$ of $5 \%$ or a restricted one of $1 \%$.

- To prove the absence of heteroscedasticity, the Glesjer test was used. Heteroscedasticity does not occur when the probability of the t-statistic for all independent variables is higher than a significance level (a) of $5 \%$.

- To ascertain the absence of autocorrelation, the runs test based on the mode was used. Autocorrelation does not exist when the asymptotic significance of Z-statistic is higher than $\alpha$ of $5 \%$.

- To detect the nonexistence of multicollinearity, the variance inflation factor (VIF) was compared with the cut-off point of 10 . Multicollinearity does not exist when the VIF of each independent variable is lower than 10.

Furthermore, to examine the regression coefficients, $\beta_{1}, \beta_{2}$, and $\beta_{3}$, t-statistic is used by comparing its probability with the significance level by indicating this following hint:

- If the probability of t-statistic is less than $\alpha$ of $5 \%$, the null hypothesis is declined.

- If the probability of t-statistic is above or the same as $\alpha$ of $\% 5$, the null hypothesis is acknowledged.

\section{RESULTS AND DISCUSSION}

This research employs 23 banks with a 9-year lifespan, bringing the total number of observations to 207. Moreover, 207 related to four variables was statistically described in Table 3 .

- For $L D R$, minimum, maximum, average, and standard deviation values are $40.22 \%, 113.30 \%$, $82.4998 \%$, and 12.88862 , singly. 
Table 3. Descriptive statistics outcome of the research variables

Source: Modified output of IBM SPSS 20.

\begin{tabular}{l|c|c|c|c|c}
\hline \multicolumn{1}{c|}{ Variable } & N & Minimum & Maximum & Mean & Std. deviation \\
\hline LDR (\%) & 207 & 40.22 & 113.30 & 82.4998 & 12.88862 \\
\hline LNGBV (decimal) & 207 & 32.58 & 34.10 & 33.4095 & 0.50900 \\
\hline LNTA (decimal) & 207 & 2.28 & 14.08 & 10.8292 & 1.76711 \\
G_NPL (decimal) & 207 & 0.0021 & 0.2484 & 0.029312 \\
\hline
\end{tabular}

Table 4. The outcome of the classical assumption tests

Source: Modified output of IBM SPSS 20.

\begin{tabular}{|c|c|c|c|c|}
\hline Classical assumption test & \multicolumn{4}{|c|}{ Description } \\
\hline \multirow{2}{*}{ Kolmogorov-Smirnov normality test on errors } & \multicolumn{3}{|l|}{ Z Kolmogorov-Smirnov (K-S) } & 1.446 \\
\hline & \multicolumn{3}{|l|}{ Asymptotic significance (2-tailed) } & 0.031 \\
\hline \multirow{5}{*}{$\begin{array}{l}\text { Glesjer heteroscedasticity test } \\
|R E S|=f\left(L N G B V, L N T A, G_{-} N P L\right)\end{array}$} & Independent variable & LNGBV & LNTA & G_NPL \\
\hline & Coefficient & -1.806 & -0.439 & -37.192 \\
\hline & Standard error & 1.066 & 0.322 & 23.550 \\
\hline & t-statistic & -1.694 & -1.364 & -1.579 \\
\hline & Probability & 0.092 & 0.174 & 0.116 \\
\hline \multirow{2}{*}{$\begin{array}{l}\text { Variance inflation factor (VIF) multicollinearity } \\
\text { detection }\end{array}$} & Independent variable & LNGBV & LNTA & $G \_N P L$ \\
\hline & VIF & 1.068 & 1.172 & 1.116 \\
\hline \multirow{3}{*}{ Runs autocorrelation test on the mode-based error } & \multicolumn{3}{|l|}{ Number of runs } & 3 \\
\hline & \multicolumn{3}{|l|}{ Z-statistic } & 0.099 \\
\hline & \multicolumn{3}{|l|}{ Asymptotic significance (2-tailed) } & 0.921 \\
\hline
\end{tabular}

- For $L N G B V$, minimum, maximum, average, and standard deviation values are $32.58,34.10$, 33.4095 , and 0.50900, individually.

- For LNTA, minimum, maximum, average, and standard deviation values are 2.28, $14.08,10.8292$, and 1.76711, one-to-one.

- For G_NPL, minimum, maximum, average, and standard deviation values are 0.0021 , $0.2484,0.029312$, and 0.0235578 , separately.

Table 4 shows the examining results of classical assumptions with the explanation as follows:

- For the normality test outcome, the asymptotic significance (2-tailed) of the Z-statistic of $\mathrm{KS}$ is 0.031 . Since this value exceeds the delimited significance level of $1 \%$, errors trace the normal distribution.

- For the heteroscedasticity test outcome, the probability of the t-statistic of $L N G B V$, $L N T A$, and G_NPL is $0.092,0.174$, and 0.116 , respectively. Since each value exceeds the significance level $(\alpha)$ of $5 \%$, the absolute error is not affected by $L N G B V, L N T A$, and GN_PL. In other words, there is no heteroscedasticity.

- For the multicollinearity detection outcome, the values of VIF for $L N G B V, L N T A$, and $G_{-}$ $N P L$ are $1.068,1.172$, and 1.116, respectively. Since each value exceeds 10 , multicollinearity does not exist in the regression model.

For the autocorrelation test outcome, the asymptotic significance (2-tailed) of the $Z$-statistic of KS shows 0.921 . Since this value exceeds $\alpha$ of $5 \%$, errors are random. As a consequence, there is no autocorrelation problem in the regression model.

Table 5 presents the regression model's estimation outcome with pooling data and shows the probability of the t-statistic of $0.0034,0.0001$, and 0.0092 for each regression coefficient, $L N G B V$, $L N T A$, and NPL, to examine the null hypothesis. Since the probability of the t-statistic is lower than $\alpha$ of $5 \%$, this study discards all the null hypotheses. This circumstance means that research hypotheses $1 \mathrm{~b}, 2$, and 3 are recognized due to a positive regression coefficient. 
Table 5. Pooled regression model estimation outcome: determinants of bank intermediary function

\begin{tabular}{|c|c|c|c|c|}
\hline \multicolumn{5}{|c|}{ Source: Modified Output of E-Views 6} \\
\hline Independent variable & Coefficient & Std. error & t-statistic & Probability \\
\hline c & -110.5315 & 55.46360 & -1.992866 & 0.0476 \\
\hline LNGBV & 5.032876 & 1.696078 & 2.967362 & 0.0034 \\
\hline LNTA & 2.031209 & 0.511735 & 3.969258 & 0.0001 \\
\hline G_NPL & 98.56370 & 37.46490 & 2.630828 & 0.0092 \\
\hline
\end{tabular}

In this study, firstly, government bond value is proven to affect bank intermediary function positively. It was proven that the government's bonds attract banks' buying intention, as Utari, Kurniati, and Surjaningsih (2011) explain. As a result, government bonds' issue to finance its budget does not compete with the bank's transitional rolein obtaining money from and lend it back to society. Based on the evidence, this research refuses the crowding-out hypothesis supported by Christensen (2005), DeBonis and Stacchini (2013), Altaylıgil and Akkay (2013), Anyanwu, Gan, and $\mathrm{Hu}$ (2017), and Mwakalila (2020).

Secondly, bank size was proven to have a positive effect on bank intermediary function. This means that big banks have the experts managing asset portfolio so that they can properly diversify risks. For that reason, they can aggressively allocate funds to society. Furthermore, this circumstance supports the study of Vodová (2011), Chagwiza (2014), Rabab'ah (2015), Boako, Acheampong, and Ibrahim (2017), El-Chaarani (2019), and Tran (2019). Finally, it has been proven that bad loans have a positive effect on bank intermediary function. This means that banks with high BL will find it difficult to manage their liquidity because of their higher LDR. Moreover, this case confirms the result of the study by Akbar and Mentayani (2010) and El-Chaarani (2019).

By showing a positive effect of government bonds on bank intermediary function, the crowding-out does not exist. The government does not need to worry about that because the commercial banks can use this opportunity by buying bonds as compensation to cover credit risk. Additionally, large banks tend to distribute more funds than small banks because they can manage the risk by forming their asset portfolios. This implies the certification of the banking officers in large banks is essential to guarantee the quality of risk management and governance. Moreover, the liquidity problem tends to belong to banks with high bad loans. To fix this problem, restructuring loans for their borrowers can become an alternative.

\section{CONCLUSION}

This paper explores the impact of the government bond value on the bank intermediary function with the samples and the data related to the research variables from the banks listed on the capital market of Indonesia between 2010 and 2018. This study infers that the government's bonds can increase the banks' channeling funds because the crowding out does not exist. As a control variable, bank size and bad loans possess a positive influence on this function.

Although three explanatory variables significantly affect bank intermediary function, this study still has some limitations, i.e., the number of explanatory variables used and the population's scope.

- Concerning the first limitation, the next scholars can add internal and external bank factors as other explanatory variables in their research model to overcome it. Examples of internal factors are the interest rate of bank deposits and loans, profitability, bank capital, capital adequacy ratio, operating expense to revenue ratio, and growth of total deposits. Meanwhile, examples of external factors are gross domestic product, inflation, unemployment, and economic development. 
- Concerning the second limitation, next scholars can combine banks listed on the capital market in Indonesia and other Southeast Asian countries as their object. Furthermore, they can utilize the stratified random sampling by treating the country as strata to create a general inference internationally.

\section{AUTHOR CONTRIBUTIONS}

Conceptualization: Rosemarie Sutjiati Njotoprajitno, Bram Hadianto.

Data curation: Melvin.

Formal analysis: Rosemarie Sutjiati Njotoprajitno, Bram Hadianto.

Funding acquisition: Rosemarie Sutjiati Njotoprajitno, Bram Hadianto.

Investigation: Rosemarie Sutjiati Njotoprajitno, Bram Hadianto, Melvin.

Methodology: Rosemarie Sutjiati Njotoprajitno, Bram Hadianto.

Project administration: Rosemarie Sutjiati Njotoprajitno.

Resources: Rosemarie Sutjiati Njotoprajitno, Melvin.

Software: Rosemarie Sutjiati Njotoprajitno, Bram Hadianto.

Supervision: Rosemarie Sutjiati Njotoprajitno, Bram Hadianto.

Validation: Rosemarie Sutjiati Njotoprajitno, Bram Hadianto, Melvin.

Visualization: Rosemarie Sutjiati Njotoprajitno, Bram Hadianto, Melvin.

Writing - original draft: Bram Hadianto, Melvin.

Writing - reviewing \& editing: Bram Hadianto.

\section{REFERENCES}

1. Abbas, S. M., \& Christensen, J. E. (2007). The role of domestic debt markets in economic growth: An empirical investigation for lowincome countries and emerging markets (IMF Working Papers WP/07/127). Retrieved from https:// www.imf.org/en/Publications/WP/ Issues/2016/12/31/The-Role-of-Domestic-Debt-Markets-in-EconomicGrowth-An-Empirical-Investigationfor-Low-20973

2. Adzis, A. A., Sheng, L. E., \& Bakar, J. A. (2018). Bank lending determinants: Evidence from Malaysia commercial banks. Journal of Banking and Finance Management 1(3), 36-48. Retrieved from https:// www.sryahwapublications.com/ journal-of-banking-and-financemanagement/pdf/v1-i3/5.pdf

3. Akbar, M., \& Mentayani, I. (2010). Faktor-faktor yang mempengaruhi intermediasi: Studi pada bank umum swasta Kalimantan Selatan tahun 2007-2009. Jurnal Manajemen dan Akuntansi, 11(2), 107-116. Retrieved from http://journal.stieikayutangi-bjm.ac.id/index.php/jma/ article/view/17/18

4. Akpansung, A. O. (2018). Analysis of the impacts of domestic debts on private sector credit, lending rate, and real output: Evidence from Nigeria. Journal of Finance and Economics, 6(3), 111-123. Retrieved from http://pubs.sciepub. com/jfe/6/3/5/index.html

5. Altayligil, Y. B., \& Akkay, R. C. (2013). The effect of the domestic debt on the financial development: A Case Study for Turkey. International Journal of Economics and Finance, 5(5), 64-74. http://doi. org/10.5539/ijef.v5n5p64

6. Anyanwu, A., Gan, C., \& Hu, B. (2017). Government domestic debt, private sector credit, and crowding out effect in oil-dependent countries. Journal of Economic Research, 22, 127-151. Retrieved from https://researcharchive.lincoln.ac.nz/handle/10182/10233

7. Benayed, W., \& Gabsi, F. B. (2020). Domestic public debt and financial development in Sub-Saharan Africa: Is there an inverted-U relationship? Economics Bulletin, 40(1), 846-854. Retrieved from http://www.accessecon.com/Pubs/ EB/2020/Volume40/EB-20-V40I1-P72.pdf
8. Boako, G., Acheampong, I. A., \& Ibrahim, M. (2017). Determinants of bank credit in Ghana: A boundstesting cointegration approach. African Review of Economics and Finance, 9(1), 33-61. Retrieved from https://www.ajol.info/index. php/aref/article/view/162143

9. Chagwiza, W. (2014). Zimbabwean commercial bank liquidity and its determinants. International Journal of Empirical Finance, 2(2), 52-64. Retrieved from https://www. academia.edu/7255722/Zimbabwean_Commercial_Banks_Liquidity_and_Its_Determinants

10. Christensen, J. (2005). Domestic Debt Markets in Sub-Saharan Africa. IMF Staff Paper, 52(3), 518-538. Retrieved from https:// www.imf.org/External/Pubs/FT/ staffp/2005/04/pdf/christen.pdf

11. Cucinelli, D. (2015). The impact of non-performing loans on bank lending behavior: Evidence from the Italian banking sector. Eurasian Journal of Business and Economics, 8(16), 59-71. http://doi. org/10.17015/ejbe.2015.016.04

12. DeBonis, R., \& Stacchini, M. (2013). Does government debt 
affect bank credit? International Finance, 16(3), 289-310. http:// doi.org/10.1111/j.14682362.2013.12037.x

13. El-Chaarani, H. (2019) Determinants of bank liquidity in the Middle East region. International Review of Management and Marketing, 9(2), 64-75. http://doi.org/10.32479/ irmm.7742

14. Ghozali, I. (2016). Aplikasi Analisis Multivariate dengan Program IBM SPSS 23 (8 ed.). Semarang: Badan Penerbit Universitas Diponegoro.

15. Hanson, J. A. (2007). The growth in government domestic debt: Changing burdens and risks (Policy Research Working Paper No. 4348). Retrieved from https:// openknowledge.worldbank.org/ handle/10986/7329

16. Hartono, J. (2012). Metodologi penelitian bisnis: Salah kaprah \& pengalaman-pengalaman (5 ed.). Yogyakarta: Badan Penerbit Fakultas Ekonomi Universitas Gadjah Mada.

17. Ivanović, M. (2016). Determinants of Credit Growth: The Case of Montenegro. Journal of Central Banking Theory and Practice, 2, 101-118. http://doi.org/10.1515/ jcbtp-2016-0013

18. Kartini, K., \& Nuranisa, A. (2014). Pengaruh capital adequacy ratio (CAR), non-performing Loan (NPL), pertumbuhan dana pihak ketiga (DPK), biaya operasional terhadap pendapatan operasional (BOPO) terhadap likuiditas yang diukur dengan loan to deposit ratio pada perusahaan perbankan yang ter. Unisia, 36(81), 142156. Retrieved from https:// journal.uii.ac.id/Unisia/article/ view/10475/8159

19. Kembuan, D. T., Rahman, I. F., \& Setiawan, N. (2018). Analisis pengaruh karakteristik spesifik bank terhadap fungsi intermediasi pada perbankan yang terdaftar di Bursa Efek Indonesia tahun 2013 sampai tahun 2017. Jurnal Riset Akuntansi dan Keuangan, 6(2), 187-210. Retrieved from https://ejournal. upi.edu/index.php/JRAK/article/ view/11645
20. Khanal, S. (2019). Determinants of liquidity in commercial banks of Nepal. International Journal of Economics and Management Studies, 6(8), 11-16. http://doi. org/10.14445/23939125/IJEMSV6I8P103

21. Mwakalila, E. (2020). Crowding out of private sector in Tanzania: Government Expenditure, Domestic Borrowing, and Lending Rates. Emerging Economy Studies, 6(1), 123-135. http://doi. org/10.1177/2394901520913653

22. Nachrowi, N., \& Usman, H. (2006). Pendekatan Populer dan Praktis Ekonometrika Untuk Analisis Ekonomi dan Keuangan. Jakarta: Lembaga Penerbit Fakultas Ekonomi Universitas Indonesia.

23. Rabab'ah, M. (2015). Factors Affecting the Bank Credit: An Empirical Study on the Jordanian Commercial Banks. International Journal of Economics and Finance, 7(5), 166-178. http://doi. org/10.5539/ijef.v7n5p166

24. Shah, S. Q. A., Khan, I., Shah, S. S. A., \& Tahir, M. (2018). Factors affecting liquidity of banks: Empirical evidence from the banking sector of Pakistan. Colombo Business Journal, 9(1), 1-18. http://doi.org/10.4038/cbj. v9i1.20

25. Siringoringo, R. (2017). Analisis Fungsi Intermediasi Perbankan Indonesia (Studi Kasus Bank Umum Konvensional yang Tercatat di BEI Periode 2012-2016). Jurnal Inspirasi Bisnis dan Manajemen, 1(2), 135-144. http://doi. org/10.33603/jibm.v1i2.865

26. Somantri, Y. F., \& Sukmana, W. (2019). Analisis faktor-faktor yang mempengaruhi financing to deposit ratio (FDR) pada bank umum syariah di Indonesia. Berkala Akuntansi dan Keuangan Indonesia, 4(2), 61-71. http://dx.doi. org/10.20473/baki.v4i2.18404

27. Suliyanto. (2009). Metode Riset Bisnis. Yogyakarta: Penerbit ANDI.

28. Surjaningsih, N., Yumanita, D., \& Deriantino, E. (2014). Early Warning Indicator Risiko Likuiditas Perbankan (Working Paper WP/1/2014). Retrieved from https://www.bi.go.id/id/publikasi/ wp/Pages/Early-Warning-Indicator-Risiko-Likuiditas-Perbankan. aspx

29. Świtała, F., Kowalska, I., \& Malajkat, K. (2020). Size of banks as a factor which impacts the efficiency of the bank lending channel. Financial Internet Quarterly, 16(1), 36-44. http://doi.org/10.2478/fiqf-20200005

30. Tran, D. V. (2019). Ownership structure and bank lending. Economics Bulletin, 39(4), 30113023. Retrieved from http://www. accessecon.com/Pubs/EB/2019/ Volume39/EB-19-V39-I4-P279.pdf

31. Uchida, H., Udellb, G. F., \& Watanabe, W. (2008). Bank size and lending relationships in Japan. Journal of the Japanese and International Economies, 22(2), 242-267. http://doi.org/10.1016/j. jiie.2007.07.003

32. Utari, G. A. D., Kurniati, I. N., \& Surjaningsih, N. (2011). Dampak penerbitan SUN domestik terhadap perkembangan sektor perbankan. Jurnal Badan Pendidikan dan Pelatihan Keuangan, 2, 81-100. Retrieved from https://jurnal.bppk. kemenkeu.go.id/jurnalbppk/article/ view/55/88

33. Vodová, P. (2011). Liquidity of Czech commercial banks and its determinant. International Journal of Mathematical Models and Methods in Applied Science, 5(6), 1060-1067. Retrieved from https://www.researchgate.net/ publication/268077272_Liquidity_of_Czech_Commercial_Banks_ and_its_Determinants

34. Wibowo, B. (2018, October 15). Crowding out pemerintah dan swasta. (T. Adi, Editor). Retrieved May 2020, 31, from https://analisis. kontan.co.id/news/crowding-outpemerintah-dan-swasta?page $=$ all

35. Wibowo, B., Passagi, H., \& Prasetyo, M. B. (2018). Uji empirik crowding out surat utang pemerintah dan korporasi di pasar modal Indonesia. Jurnal Ekonomi Kuantitatif Terapan, 11(1), 19-33. http://doi.org/10.24843/JEKT.2018. v11.i01.p02 